\title{
Marcelo Casacuberta
}

Marcelo Casacuberta (Montevideo 1965) es fotógrafo y realizador audiovisual. Trabajó durante 17 años en fotoperiodismo, en medios como La Repúblicay El Observador. En los últimos tiempos, su profesión y el interés por la naturaleza se integran en varias de sus más recientes producciones audiovisuales: libros, películas documentales y series de fotografías, muchos de los cuales le significaron importantes premios. Con su película documental Río de los pájaros pintados, que relata la diversidad de la fauna autóctona de nuestro pais, obtuvo el primer lugar en la categoría largometrajes en el Festival Cinecien (Festival de Cine y Video Científico del MERCOSUR) 2009 de Argentina, así como el premio UNICEF en el festival Divercine 2009 de Uruguay. "Río Negro", también largometraje documental, obtuvo el premio a la Mejor Producción Uruguaya en el Festival Divercine 2010 de Uruguay. $\mathrm{Ha}$ expuesto, de manera individual y colectiva, en diversos espacios en Uruguay y Brasil. En esta selección para dixit se exhiben fotografias que el autor realizó en Isla de Lobos (Maldonado, Uruguay), durante el rodaje de un documental en el que trabajó.
Marcelo Casacuberta (Montevideo 1965) is a photographer and audiovisual producer. He worked 17 years in photojournalism, for newspapers such as La República and El Observador. His profession and interest for nature have been recently integrated into several of his audiovisual productions: books, documentaries and photographs series, many of which have earned him major awards. With his documentary film Rio de los pájaros pintados, which shows the diverse native fauna of our country, he won the first place in the feature film category at the Cinecien 2009 Festival in Argentina and the UNICEF Award at the Divercine 2009 Festival in Uruguay. With Rio Negro, also a documentary film, he was awarded for Best Production at the Divercine 2010 Award Festival in Uruguay. He has exhibited his work both individually and collectively in Uruguay and Brazil. This is a special selection for dixit of photographs that the author took at the Isla de Lobos while filming one of his documentaries. 

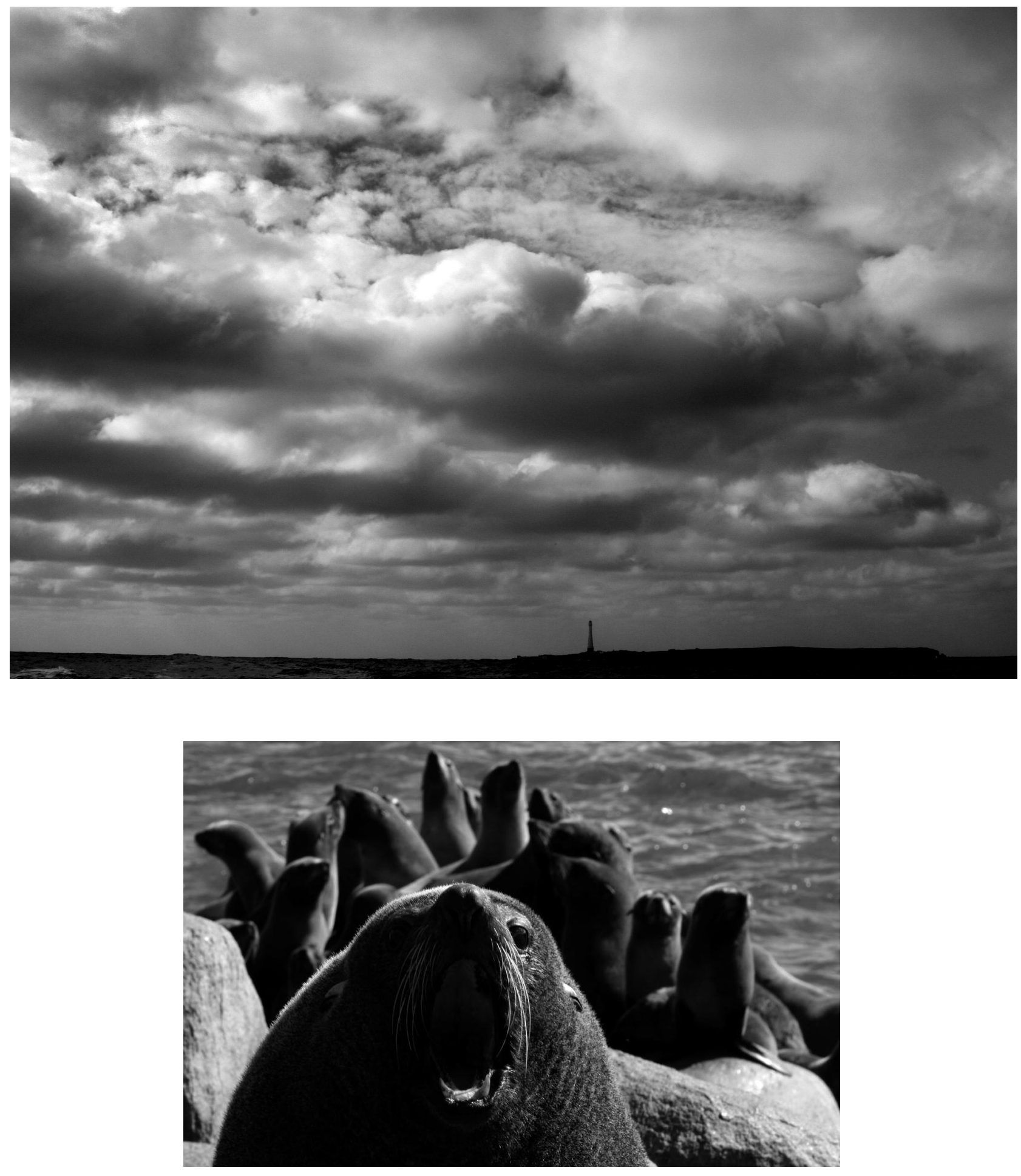

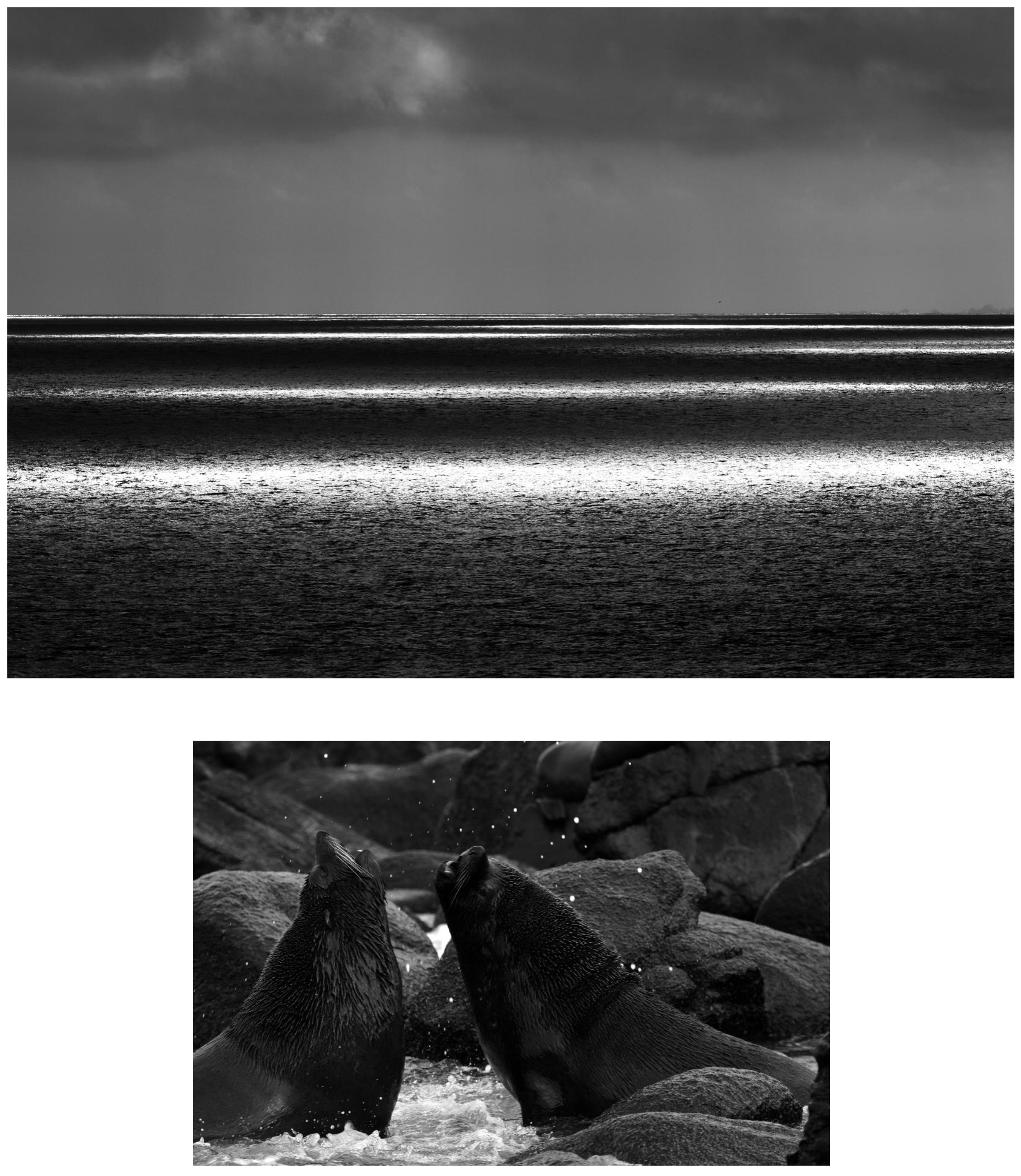

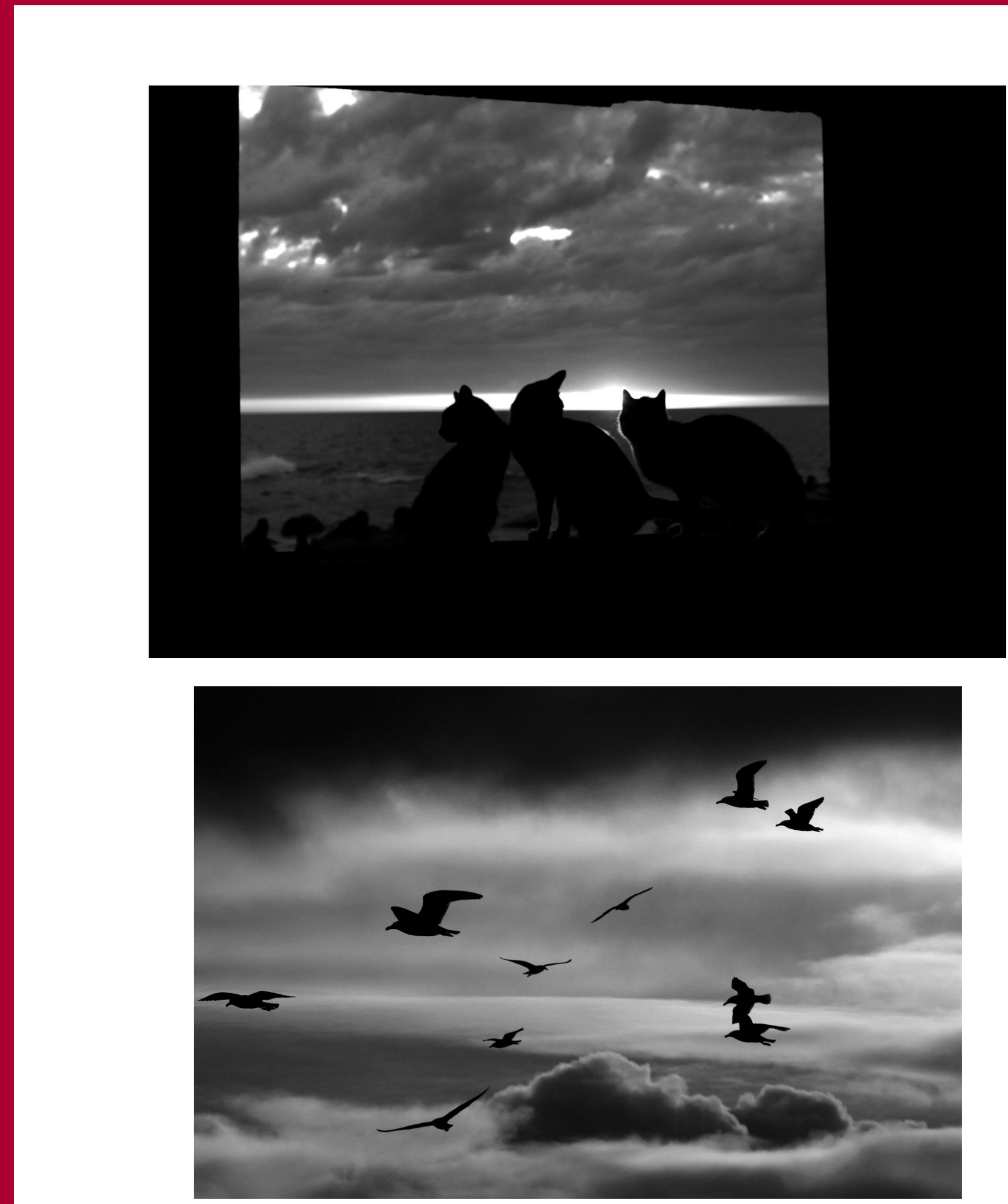

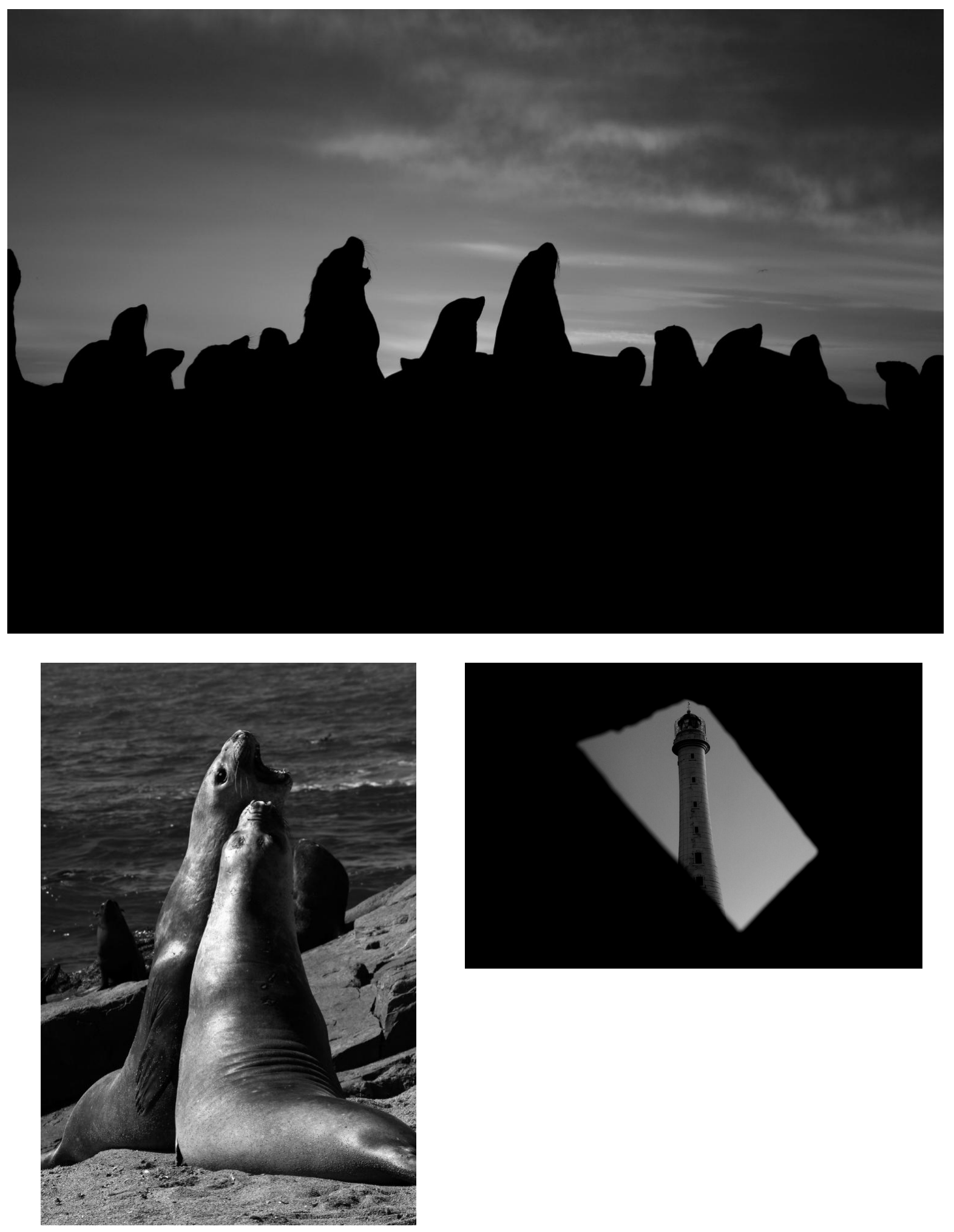
A la Isla de Lobos fui como camarógrafo, en un documental de otro realizador, y mientras filmábamos las secuencias era inevitable que yo fuera sacando algunas fotos, ya sea de los animales, del rodaje o del entorno de la isla. Sacaba fotos más bien centradas en los lobos y sus conductas, mezcladas con otras que buscaban más lo estético, la composición, una cierta luz. Son dos fases que conviven en mí: el fotógrafo de fauna y el fotógrafo plástico. En algunas fotos, esos dos fotógrafos se mezclan; en otras, trabajan en forma más independiente.

Estar en medio de un bañado esperando la llegada de los animales es un tiempo de disfrute, inclusive si no surge una toma o una foto. Estar ahí es el premio, el objetivo; la foto o la toma es el pretexto. Son momentos de espera en los que sentís una emoción derivada de algo muy primario y básico: el contacto con la naturaleza. Sentir los sonidos de los animales y los olores de la vegetación, prestar atención al canto de los pájaros para identificar qué especies están cerca y se podrían filmar. Tratar de anticiparte a los animales, intuir dónde van a estar y cómo acercarte sin que te noten. Si lo pensás bien, es una escena que, salvo por la cámara, podría haberse desarrollado hace diez mil años.

Hay una vorágine cuando filmás una araña atrapando su presa, o a un pájaro que persigue a otro intentando cortejarlo. Si estás quieto, inmóvil, mientras ves que se aproxima a lo lejos una mulita, y permanecés sin moverte entre unas ramas esperando que se acerque los suficiente como para una toma, también ahí hay una adrenalina interna, sin acción ni movimiento, pero con mucha tensión por ver si al final lográs filmarla.

Marcelo Casacuberta 